\title{
Domestic work, learning, and literacy practices across transnational space
}

\author{
Amy North
}

\section{Abstract}

This paper explores the learning experiences and literacy practices of a group of female migrant domestic workers from Nepal, reporting on ethnographic data collected between 2008 and 2013. Drawing on the conceptualisation of literacy as a social practice, as well as the notion of translocational positionality (Anthias 2002, 2006, 2008), it examines the way in which the women's emerging literacy practices in English interacted with their experiences as migrant workers. It argues that understanding the transnational nature of the women's lives is essential to understanding the complex ways in which literacy was threaded through their social and material practices. In doing so it points to the need for a more complex conceptualisation of context and of the relationship between the local and global within literacy research, which pays attention to the way in which literacy practices interact with processes entailing movement and positioning across boundaries and between different transnational spaces.

Keywords: Literacy, migration, domestic work, gender, ESOL 


\section{Introduction}

When I got the letter from the home office I could read what it said, there was just one word I didn't know... and I had to go and ask my employer... Now it is much easier to know how to go places, for an interview or something. I know the postcodes NW3, $N W 1 \ldots$

Priya $23 / 04 / 08$

Sunita said that she was thinking of getting a laptop, which she wants to bring to class so I can teach her how to open an email account and Facebook. She [said] that people always ask her about her email... and if she's on Facebook, and why not - if she lives in London she should be - and she [said] "Ijust lie and make up that it's because I haven't had time”.

My observation notes 20/01/10

Priya and Sunita ${ }^{1}$ are both migrant domestic workers from Nepal, who, over a period of three years attended literacy support sessions that I ran at the Migrant Support Centre (MRC) in London, along with eight other women. All the members of the group came from Nepal, except for one member who was from India, and at the time, all were living and working in London, employed as domestic workers in wealthy households. Like the other members of the group both Priya and Sunita had left home to start work as migrant domestic workers at a very young age. They therefore had had very little formal education and limited opportunities to develop literacy skills in their own country or language. Living and working in London had therefore not only entailed encountering new literacy demands, but also had represented an opportunity to learn to read and write - in English - for the first time.

\footnotetext{
${ }^{1}$ All names used are pseudonyms
} 
As migrant domestic workers, the women in the group form part of a growing body of migrant women: $83 \%$ of the estimated 53 million domestic workers worldwide are women (ILO, 2015), employed in private households as cooks, cleaners and nannies. The nature of live-in domestic work, and the complex, gendered, asymmetrical relations of power and dependency that exist between domestic workers and their employers make migrant domestic workers particularly vulnerable to abuse and exploitation, and this is often compounded by immigration regulations. Although at the time that the research discussed in this paper was conducted, migrant domestic workers were able to enter the UK with their employers on domestic worker visas, in the context of a changing political context, the women in the group were acutely aware of the insecurity of their immigration status as domestic workers ${ }^{2}$. They were keen to apply for indefinite leave to remain, which they could do after five years in the country, subject to attending a combined ESOL and citizenship class and passing an oral test English language test ${ }^{3}$. However, as a number of researchers have noted, the tensions entailed by the requirement for migrants to attend citizenship classes in a context of increasing funding cuts to the ESOL sector meant that, at the time of this research, these classes were often poorly resourced and teachers under supported (see, for example, Baynham et al., 2007; Han, Starkey, \& Green, 2010; Simpson, 2015). As a result, although most of women in the research group attended ESOL and citizenship courses, they often struggled to engage with them, and found the literacy demands of the ESOL classroom particularly challenging. The literacy support sessions that they attended with me, were therefore intended to complement their experiences of ESOL learning, and help them develop their skills and confidence in reading and writing English in a small group setting. In this paper I discuss qualitative data

\footnotetext{
2 And indeed, under the Conservative government, the domestic worker visa was changed in 2012 - under the new visa domestic workers entering the country after 2012 are not legally able to change employers and are not able to extend their visas beyond six months (Kalayaan 2015)

${ }^{3}$ In October 2013 these regulations were changed and all migrants seeking indefinite leave to remain are now required to take the 'life in the UK test' and show progression in English language skills (Home Office, 2013).
} 
that I collected with the women, through the observation of these weekly literacy support sessions, as well as life history interviews and the documentation of group and individual informal discussions that I held with the group of women over a five year period (20082013), in order to reflect on the way in which they engaged with literacy. In particular, I consider how the women's literacy practices affected and were affected by the transnational nature of their lives and experiences as migrant domestic workers navigating across and moving between different spaces as they negotiated life in London, while staying connected to their families and communities in Nepal and India and across the globe. In doing so I engage with recent debates within the New Literacy Studies regarding the relationship between the global and the local in literacy practices, and draw on Floya Anthia's notion of 'translocational positionality' (Anthias 2002, 2006, 2008) to consider the ways in which the literacy practices the women engaged with within the workplace, as they interacted with their extensive social networks, and as they negotiated immigration bureaucracies, were bound up in 'translocational' social processes (Anthias 2008, p8), entailing movement and positioning within and between multiple, and shifting locales.

\section{Understanding literacy in local/global contexts}

Literacy, what it means, and what it does, has long been a subject of debate within the social sciences. Writing in the 1960's anthropologists Goody and Watt (Goody \& Watt, 1968) argued that writing as 'a technology of the intellect' (Goody, 1986), was central to enabling an expansion of the range of activities conducted by individuals and cultures, and heralded with bringing about significant social and economic changes. However, while this view has continued to hold considerable sway within policy circles (Robinson-Pant, 2004b), it has been subject to trenchant critique from within the research community. From the 1980s 
ethnographic research highlighted the significance of understanding differences between schooling and literacy and pointed to particular meanings of literacy and orality among different cultural groups (see, for example, Heath, 1983; Scribner \& Cole, 1981a, 1981b). In 1984, Brian Street made the case for an 'ideological' model of literacy which considered literacy to be a social practice, embedded in relations of power and locally defined social and cultural values (Street, 1984, 1994). In doing so he argued for the need to move away from an 'autonomous' model of literacy, which conceptualised literacy as a neutral technical skill, or which viewed literacy difficulties as 'autonomous' problems that can solved in isolation from the larger social structures and power inequalities within which they are located (see, for example, Street, 2003).

Since then, an extensive body of ethnographic research associated with the New Literacy Studies, has examined literacy as a social practices, often focusing on the experiences of adult literacy learners, many of whom are women, in developing countries (see, for example, Chopra, 2004; Kalman, 2005; Robinson-Pant, 2001). Such studies have drawn attention to the way in which literacy practices are embedded within particular social and cultural contexts and the relations of power they bring with them. Much of this ethnographic research has emphasised the primacy of the local context in shaping literacy practices, pointing to the way in which the uses, values and meanings associated with literacy are contingent on the local context in which they are situated.

However, more recently, particularly in the context of increased concerns with understanding processes of globalisation, some commentators have questioned the validity of such a localist approach. Writing in 2002, Brandt and Clinton, in an influential paper "the Limits of the Local", argued that the New Literacy Studies has tended to exaggerate "the power of the local to define the meanings and forms that literacy takes" (p. 337) and suggested that paying greater attention to global contexts is essential for understanding local literacy practices. 
While recognising the important role that paying close attention to context has played in enabling deeper understandings of literacy practices, they argued for the need to also consider "transcontextual" aspects of literacy, asking:

"Can we not see the ways that literacy arises out of local, particular, situated human interactions while also seeing how it also regularly arrives from other places infiltrating, disjointing, and displacing local life?" (Brandt and Clinton, 2002, p. 342343)

Since then, this concern with paying closer attention to understanding and theorising the global as well as local dynamics of literacy has been expressed by a number of researchers from within the New Literacy Studies (see, Baynham \& Prinsloo, 2009; Hamilton \& Pitt, 2011a; Pahl \& Rowswell, 2006; Reder \& Davila, 2005). Baynham and Prinsloo, for example, have pointed to a need to temper the focus on locally located literacy practices 'with a sense of how remote sites and remote literate practices shape and constrain local literacy practices' (Baynham and Prinsloo, 2009 p. 4). Similarly, Maddox (2007), has suggested that the 'situated' approach to literacy (Barton et al., 2000), may be useful in enabling 'new theoretical perspectives to be explored about the potentialities of literacy and the ways in which large-scale, often global traditions and practices are expressed and experienced within local contexts' (p255).

In these conceptualisations of the relationship between the local and the global in relation to literacy practices, the suggestion is that, although literacy practices are locally situated, global processes may play out in and affect local contexts and practices in particular ways. This is something that has been explored empirically through studies examining how global dynamics have influenced literacy practices in particular localities (see, for example, Cheffy, 2011; Papen, 2007; Tamtomo, 2012). Here the focus is still very much on the local space 
itself, however elsewhere attention has turned to what happens when literacy moves out beyond 'the local', as texts or people move between contexts. Blommaert and Kell, for example, have examined the processes of recontextualisation that occur, as written materials move beyond the local space (Blommaert, 2001, 2008; Kell, 2006, 2009, 2011). Other studies, have explored the literacy practices of people who - like the women in my own research - move between different countries and global spaces as migrants, often drawing on the notion of transnationalism, to consider the literacy practices of 'transmigrants' (Glick Schiller et al, 1995; Pries, 2008). This research has pointed to the way in which literacy practices may be influenced by or facilitate transnational movement, how they are affected by transmigrants' continued connections to their communities and countries of origin, and examined the role that they play in maintaining social networks and connections 'with home' (see for example, Baynham, 2007; Lam \& Warriner, 2012; Meyers, 2014; Sarroub, 2009; Warriner, 2007).

Meyer's (2014) study of literacy practices of transnational migrant students moving "both geographically and metaphorically" (p3) across the Mexico US border, for example reveals the interconnectedness of the local with the global. She points to the ways in which literacy is affected by migration as well as other economic and social processes, and argues that, in relation to these experiences, "it has become insufficient to discuss literacy in a single, cultural context because literacy has become quite literally transnational" (ibid, p. 6). Sarroub's (2009) research with young Yemeni and Iraqi immigrant and refugee men and women considers howthey "strive to become literate as they negotiate transnational spaces" (Sarroub, 2009 p. 63), and like, Meyer's research, points to the way in which the participants' literacy practices are bound up in the transnational nature of their lives and identities. In these studies, the relationship between the local and the global - and what this means for understandings of context - is clearly rather more complex than that outlined above. In both 
studies, the contexts in which the literacy practices of the research participants are situated are complex, multiple, and shifting, reflecting the transnational dimensions of the participants lives, and the ways in which they are engaged in negotiating their lives, identities, and relationships with others as they move between very different cultural and geographic spaces.

Like the participants in Meyers' and Sarroub's studies, the lives of the women who participated in my research had complex transnational dynamics, as they navigated across and between multiple and shifting contexts, and this had significant implications for their literacy practices. Research that has considered the experiences of migrant domestic workers has emphasised the way in which migrant domestic women as transmigrants, may inhabit transnational social worlds as they move between their country of work and their countries of origin, and are often connected into communities of domestic workers working across the globe (see, for example, Bridget Anderson, 2001; Lutz, 2011; Lutz \& Palenga-Möllenbeck, 2011), and this could be seen clearly in the experiences of the women in the group.

While the women participating in the research can't be seen as a homogeneous group - they each had slightly different experiences and were at different stages with regard to their age, employment or immigration status, all shared similar experiences of leaving their families and communities in rural Nepal or India at a young age to begin work as migrant domestic workers. Although one group member - Ramita - had completed primary school, most of the women in the group explained that they only attended school for a year or two, or not at all. Priya, for example, explained how she left school to work in the city (Kathmandu) when she was eight or nine, after being hit by her teacher. Similarly, Nhanu had left her village when she was eleven to make carpets in Kathmandu, before leaving to work as a domestic worker in India when she was fifteen. From India she went to Hong Kong, where she worked for ten years before coming to London. 
Like Nhanu, most of the women had come to the UK via time spent in one or more other countries - which included India, Hong Kong, Dubai and Spain - and all worked in international households, with employers who were neither from the UK or Nepal. The time that they had spent working in the UK when they joined the group ranged from three to ten years. During this time although one had obtained a British passport, most of the others held domestic worker visas and were hoping to obtain indefinite leave to remain in the UK. One Priya - was struggling to obtain a valid work visa. Meanwhile, all maintained close links to their home communities: several had children or grandchildren back in Nepal, two of the women - Nhanu and Ramita - returned to Nepal to get married over the time period this research was conducted, and others spoke proudly of the remittances they sent back to their villages. They also maintained close contact with their extensive networks of friends and family from Nepal, as well as other domestic workers, spread across the globe.

The women's experiences of domestic work had not always been easy: as has been documented in relation to other groups of migrant domestic workers (see, for example, Anderson, 2000; Briones, 2009; Cox, 2006; Hondagneu-Sotelo, 2007; Lutz, 2008; Parreñas, 2001), they all shared experiences of abuse, exploitation and long working hours, as well as the sadness of separation from family and communities. In an earlier paper (North, 2013), I examined this, in reflecting on the life stories and experiences of two of the women in the group, drawing on McNay's $(2000,2008)$ conceptualisation of 'agency in constraint' to consider the way in which they negotiated the tensions, dislocations and gendered power relations that they encountered as domestic workers and migrant women.

In this paper, I turn my attention to the literacy practices of the group as a whole, and the way in which literacy interacts with their experiences across distinct - but overlapping - domains: the workspace (comprising the international households in which they live and work), the social space associated with the transnational social networks, and the official space linked to 
the immigration bureaucracies that they encountered as they move between Nepal and the UK, and negotiated live as migrants. In doing this, I have found it helpful to draw on Anthias' $(2002,2006,2008)$ notion of 'translocation positionality' as a lens to inform my analysis. For Anthias, the term positionality brings together a concern with both structure and agency through reference to "social position (as a set of effectivities: as outcome) and social positioning (as a set of practices, actions and meanings: as process)" (2008, p15), whilst 'location' points to the need to consider "context, the situated nature of claims and attributions and their production in complex and shifting locales" (ibid). The notion of 'translocational positionality' therefore "not only focuses on the crisscrossing of different social locations, but also relates to the shifting locales of people's lives in terms of movements and flows' (2008, p. 17). In this paper, I suggest that this conceptualisation may represent a useful framework for unpacking how literacy interacts with - affecting, and being affected by - processes involving social positioning in complex and shifting contexts.

\section{Methodology}

The data reported on in this paper was collected between 2008 and 2013. Between 2008 and 2011, I met members of the group - comprising eleven women in total - on a weekly basis through running an informal literacy support group. Over this period I documented a total of 63 of these sessions, taking detailed observation notes, and making copies of texts associated with the sessions. These included learning materials used and writing produced during the sessions themselves, as well as texts the women brought in with them, for example material from other lessons they attended, SMS text messages, immigration or employment forms and letters. I also conducted detailed life history research with three of the women. For two women this was done through carrying out in-depth semi structured interviews (in 2008 and 2013). For the other woman this was through the documentation of frequent informal discussions held before and after the literacy sessions themselves, as well as in 2013. 
In developing my approach to collecting and analysing my data I drew on insights from the extensive body of ethnographic research that has considered literacy as a social practice (for example, Aikman, 1999; Barton \& Hamilton, 1998; Chopra, 2001, 2004; Heath, 1983, 1996; Kalman, 2005; Maddox, 2005; Robinson-Pant, 2001). However, my research did not take the form of a classic ethnography: the nature of the women's lives, the way they were physically scattered across private households in wealthy parts of London, their movement between different geographical and social space, and the nature of their relationships with employers in whose households they lived as well as worked, meant that, except in one case, it was not possible for me to able to collect direct observation data relating to their lives and engagement with literacy outside the sessions.

Instead I drew on elements of an ethnographic approach to inform the way in which I conducted data collection in relation to the literacy support sessions themselves, drawing on the notion of the literacy event as a methodological and analytical tool (Heath, 1983; Moss, 2007). I considered that the literacy support sessions I ran could be considered literacy events - time bound moments in which "the role literacy plays in the immediate social interactions between participants becomes available for study' (Moss, 2007, p. 40). These occurred in a particular context: the women came together specifically for literacy support, the sessions took place in a small classroom or meeting room and in a centre offering a range of educational (and other support) services to members of migrant communities. However the informal nature of the sessions themselves, and way in which the content of literacy learning that took place within them was negotiated between the different participants, meant other contexts - and discussion of other events - were brought into the session space. For example, the women often used the session time, to share updates about friends and family from their communities back home, or discuss their immigration concerns or working lives and relationships with employers, and frequently brought in texts from outside the sessions which 
they wanted me to help them read or respond to. This meant that by analysing the interactions that occurred within sessions, I was able to trace the connections between observed literacy events in the sessions and other related events discussed by the women. The group sessions thus provided an opportunity not only to examine the women's engagement with literacy within the specific context of the group itself, but also to try and understand how this linked to the wider, shifting, contexts of the women's lives, and the ways in which they encountered and drew on literacy as they moved between different transnational spaces. Meanwhile, conducting interviews and collecting more detailed life-history data with selected group members, enabled me to situate their current literacy practices within the broader contexts of their life experiences both in the UK and in Nepal.

In developing my analysis, as presented in this paper, I thus combined a focus on identifying and analysing literacy events, with the analysis of life-history narratives, developed in relation to interview data, and of themes that I identified through the observation data from group sessions. In working in this way across themes, events, and narratives, I moved backwards and forwards between the language used by the participants as they identified significant moments in their lives or particular topics of concern to them in their conversations and writing and my own analytical categories, which spoke to the transnational nature of their lives and the way in which their literacy practices interact with the dislocations in time, space and language that they experienced as migrant women moving between different spaces. Through this process I sought to move from a focus on description describing what happens in the sessions, or what the women do with literacy - to developing a "language of enactment" (Moss, 2001), as I sought to conceptualise and understand the ways in which literacy played out in the tension points created by migration and domestic work, and the transnational dynamics that this entailed. 
In the following sections I develop this analysis through a discussion of the women's practices and engagement with literacy within three domains of their lives: the workplace, their social networks, and their engagements with immigration officials. In doing so I consider how they drew on their emerging literacy practices in English, as they negotiated their working lives, their relationships with friends and family, and the official bureaucracies they encountered as migrants moving between the UK and Nepal.

\section{Workplace literacies}

Maybe if we had a good education we could find a nice job but we don't, we didn't get an education we can't read and write, all we can be is domestic workers

Nhanu, 24/06/09

When the women in the group spoke about their experiences of starting work, they all emphasised that not having an education or literacy skills, which might have opened up other opportunities for obtaining more desirable 'office jobs', meant that they had little option but to become domestic workers. Domestic work was thus seen as something that literacy skills were not needed for, and this was reinforced by the way in which, when I asked them about the way in which they needed to use literacy in their daily lives, literacy practices associated with work were rarely mentioned. When asked about reading and writing in relation to her work, Nhanu for example, explained:

Sometimes it is important for text messages if my employer sends them to me. But not for cleaning in the house (01/05/13)

In some cases, when I asked women in the group directly about how they used literacy in their work context they described their own personal engagement with reading and writing in their employers' households, but this did not necessarily relate to literacy practices directly 
associated with the tasks they were required to perform as part of their jobs. Rather, as can be seen in the extract below, they described the way in which they engaged with literacy privately, often in the safety of their own room, as they practiced their reading and writing, and drew on their emerging literacy skills as a way to carve out space for their own personal reading, learning and interests:

I asked [Sudha and Jyothi] if they ever use or need to use reading and writing for their work. Sudha said she only does reading and writing at work when she does her 'homework' for this session and her Sunday class, and that is when she is in her room on her own - so it is time just for her. Jyothi said that sometimes she tries to write shopping lists but she struggles to spell all the words properly. Sometimes her employer tries to see what she is writing and she feels embarrassed and covers it up. (Observation notes 28/07/09)

Research with domestic workers in other contexts has revealed a range of literacy practices used by domestic workers in the workplace - for example reading instructions when preparing breakfast, or writing phone messages - but suggests that these practices are often so deeply embedded that they were not recognised as literacy by the domestic workers themselves (see Nabi, 2009; Papen, 2007). Over the time that I worked with the women there was some evidence of their engagement in similarly invisiblised practices - for example those associated with shopping, writing shopping lists and reading supermarket signs and labels. However, on the whole, the data that I was able to collect suggests that, for most of the participants, using literacy was not considered by them to be a significant aspect of being able to perform the cooking, cleaning and caring duties that their roles as migrant domestic workers entailed. 
What was clear was that the way in which the women engaged with, and spoke about literacy in relation to the workplace was very closely bound up in the highly literate nature of the households in which they worked, and the elite, international space that they represented. All worked for well educated, international families, often with school aged children. In some cases this provided them with access to particular forms of literacy resource, and also influenced their literacy aspirations. One group member, for example, when explaining that she wanted help learning how to use email, said that this was because she was she was able to use her employer's computer. Others members of the group were clearly familiar with a range of their employers' children's reading materials, particularly the storybooks and novels that they read. Sunita, for example, the youngest member of the group, requested that we spent time looking at teenage fiction, like that read by her employer's daughter, describing this as "girl and dog stories". Another group member, Sudha, sometimes copied out extracts of her employers' teenage daughter's books into her exercise book, and on one occasion showed me a drawing of sleeping beauty, with the words 'sleeping beauty' written below in joined writing, that she said her employers' daughter had done for her.

However, although for some group members, the literacy environments represented by the households in which they work therefore provided opportunities to access resources, they also meant that their developing literacy skills and efforts to learn to read and write in English did not appear to be particularly valued or recognised by other household members. While, none of the women suggested that their employers actively prevented them from attending classes, it was clear that did they did not make particular allowances in order to support or encourage their participation in learning. Indeed, the nature of their live-in work, and the long hours entailed, constrained their ability to continue to develop literacy skills, as they had little free time to attend additional classes or practise privately. Meanwhile, as explored further below, despite their efforts to improve their literacy skills in English, the 
women continued to rely on their employers as literacy intermediaries when, for example, reading a letter regarding their immigration status. This clearly left them vulnerable to exploitation, and constrained their ability to look for alternative work. Their emerging literacy skills in English therefore did not appear to have a significant impact on the on their status within their workplace or affect their marginal positioning within the complex power dynamics of the household as a workplace, which were mediated by gender, class, race and ethnicity.

\section{Social literacies}

In contrast to the lack of emphasis that the women placed on literacies associated with the workplace in discussions within our sessions, forms of literacy associated with their social worlds were given considerable attention. As documented for other migrant domestic workers (Madianou \& Miller, 2011; Parreñas, 2005b), mobile phone technology represented an essential part of staying connected with friends and family, in the UK, back home, and in a range of countries across the world. All the women had mobile phones and the forms of literacy associated with mobile technologies were integral to the women's literacy practices. In particular, being able to read and send text messages was established early on as a learning priority for all the women, and for some of the women the role that literacy could play in helping maintain their global social networks, appeared to be a significant motivating factor in continuing to develop and use their emerging literacy skills.

Although when they started coming to sessions few of the women could send SMS messages, by the time that the research finished most were able to do this confidently. They told me that they used SMS messages to contact each other as well as for keeping in touch with family and friends at home. The extract below, which describes a literacy event that took place in 
one of our group sessions, is particularly illustrative in revealing the transnational - and translingual - nature of the women's engagement with SMS texting:

[before the others arrived] Sudha was telling me how Nhanu spent so much time speaking on the phone and that she didn't like to talk on the phone for too long. She said that she thought that this was one of the reasons Nhanu wasn't able to learn reading and writing even though her spoken English is very good...

...she said she [Sudha] now could send simple messages as well as read the ones she got. She got her phone out to show me a message she had received from her younger sister who is now working in Egypt. The message read "My daer [Sudha] di hi how r u a mainy mainy dashera injoye u ok love u"... She had also received one from her sister in Knightsbridge thanking her for her message and saying happy dashera back. She said she had sent one saying happy dashera... which she said is a Hindi festival they celebrate in Nepal.(Observation notes 30/09/09)

This message, which, like many of the SMS texts that women in the group showed me, mixed languages, using English script, but some Hindi words, was exchanged between two Nepalese sisters, living in Egypt and London. Through it Sudha was able to connect with her sister in Cairo and also to an event of cultural significance to her as a woman from Nepal.

In detailing both the way in which Sudha spoke about Nhanu's use of the phone, and the way in which she described her own engagement with the Dashera messages, the extract above also reveals something about the importance that Sudha attributes to texting. While Sudha clearly also used her phone to call family and friends, she spoke disparagingly about the time that Nhanu spent talking on the phone - something she had similarly done on other occasions -, contrasting this to her own use of SMS. In doing so she suggests a hierarchy between the different forms of communicative practice associated with mobile phones, with sending SMS 
messages positioned as superior to a spoken phone call. As well as texting representing a useful way of maintaining connections with family and friends, by sending messages such as the message described above she is therefore able to position herself as literate in her relationships to others within her social networks. A few weeks later Nhanu alluded to this, commenting on the messages that Sudha had sent:

at the end of the session Nhanu commented on how Sudha knows so much now and how she knows that Sudha can even send text messages now - her niece had told her that she had received a text message from Sudha saying happy Dashera.(Observation notes 21/10/09)

These comments not only illustrate how connected both the women were to their extended transnational - social networks, but also affirm the status that literacy - in this case represented by the sending of an SMS message - held within these, and the value they placed on texting as a form of communicative practice associated with literacy success.

For Sudha, the use of SMS texting rather than always speaking on the phone also affected the way in which she managed some of the tensions in her relationship with her children entailed by her experiences of the long distance mothering. For example, she explained that she preferred to exchange SMS messages with her (adult) daughter rather than speaking to her directly as that way they didn't argue, which they often did when speaking on the phone (18/08/09). Sending SMS messages thus entailed processes both of connection and distancing. It enabled her to stay in touch with her daughter, to feel connected to her, and to fulfil her obligations as a 'transnational mother' (Hondagneu-Sotelo \& Avila, 1997), while facilitating the maintenance of boundaries, as she protected herself emotionally by limiting contact to the exchange of short messages rather than potentially difficult conversations. 
As discussed above, in addition to mobile phones, some group members also had access to computers through their employers. However, although in a relatively early session one group member - Ramita - spoke about wanting to send emails, at the time this did not appear to be something that was familiar to others in the group. Only Sunita, as seen in the extract at the beginning of this paper, spoke about wanting to be able to use different forms of social media as a way of keeping up with her friends. For her, being able to do use Facebook and email was not just seen as way of keeping in touch with others, but was something that was expected of her as someone living in an international city like London. The significance and status she attached to engaging with social media in this way meant that she preferred to lie, rather than admit that she lacked both the literacy and technological skills and resources required to set up and use social media or email account. We did not spend time looking at computers or social networking technologies in our group sessions. However, when I met again with some members of the group in 2013, it was clear that Facebook had become an important means of communication for some of them. Advances in mobile phone technology, meant that accessed Facebook on their phones, rather than needing to be able to access or know how to use computers.

Developing the particular literacy skills associated with mobile technologies, was clearly a very important dimension of the ways in which the women in the group maintained, managed and positioned themselves within their transnational social networks, as well as managing their connections to 'home'. These social networks which included other Nepalese migrants in the UK as well as overseas also provided them with important literacy support. When speaking about their use of mobile phones for example, some of the women told me that it was Sunita who had first showed them how to send SMS messages. They also spoke about the ways in which they received help from each other, and from other friends and family members when trying to develop literacy skills in Nepalese. Sudha, for example, was 
learning Indian letters with the help of her sister, who in turn had been taught by another migrant domestic worker while she was working in India, highlighting the existence of a transnational literacy support network connecting migrant domestic workers from and working in different countries and continents.

Meanwhile, despite the status attached to literacy in English, learning to read and write in Nepalese as well was an important aspect of maintaining links to home for many of the women, particularly in the context of trips back, or hopes to eventually return to live in Nepal. Thus, for example, shortly before she returned to Nepal to get married, Ramita stopped attending sessions so she could spend the time improving her written Nepalese, with the help of a private tutor. Priya, meanwhile, told me that her father was very proud of the way in which she had learnt to read and write in English since she had been here. But, in the light of the changes that she knew had occurred in Nepal and in her own community, she felt learning literacy skills in Nepalese was also important - which is why, as well as supporting her husband's learning, she spoke of hoping to be able to get a tutor herself sometime in the future.

The ways in which they spoke about their lives and relationships suggest that in contrast to their low status within the households within which they worked, the women were held in high regard in their home communities. This was clearly in part tied to their role as providers, sending remittances back to their communities, and they spoke proudly about how they had supported family members through education, and bought property, and, in the case of Priya, even paid for a temple in her village. However, an analysis of the way in which they engaged with literacy - through mobiles and social media - in managing relationships with friends and family at home, as well as elsewhere suggests this also played a role in shaping how they positioned themselves in and negotiated these relationships. 


\section{Official literacies}

In negotiating their position as immigrant workers in the UK, all the women found themselves being required to engage with and respond to a range of forms of literacy associated with official bureaucracies. Literacy practices associated with visas and immigration status were a particular concern of almost all the group members. When they joined the group most of the women held domestic worker visas. They hoped, in time, to be able to apply for indefinite leave to remain in the UK, and, at least initially, this was one of their major motivations for improving their literacy skills in English.

Over the period during which this research was conducted, most members of the group managed to obtain indefinite leave to remain. At the time, doing this required meeting the English and Citizenship requirements in force at the time: either passing the 'Life in the UK' citizenship test or, for applicants with lower levels of English, completing an 'ESOL and Citizenship' course in lieu of the test (Simpson, 2015). One group member, Ramita described doing the 'Life in the UK' test on the computer, explaining that she had to take it three times before she managed to pass. Others took oral English tests, following Sunday ESOL and citizenship courses:

I had to do an exam, I went to Liverpool Street for classes like Sudha. I did a spoken exam but I also had to fill in a form. I managed to do that because of what I learnt from the classes with you. (Nhanu 01/05/13)

However, for the women in the group, the procedures involved in actually obtaining their visa went far beyond simply filling in a form and passing the test. Rockhill, in discussing how immigrant women in the U.S. negotiate the literacy requirements of official bureaucracies, described "the multiplicity of interlocking, ambiguous, bureaucratic regulations with which they must be familiar" (Rockhill, 1993, p. 165). The experiences of 
the women in the case study group were similar. Nhanu for example, described to me the complex negotiations she had to carry out with current and previous employers in order to be able to produce the financial data required to satisfy immigration authorities. For Priya, the process was even more complex and drawn out, and obtaining firstly a valid domestic worker's visa, and then, eventually, indefinite leave to remain, took several years. In navigating the complex literacy demands she encountered during this process - which entailed years of extensive engagement and correspondence with lawyers and Home Office officials, as well as a journey to the passport office in Liverpool - she relied on help from literacy intermediaries including me as well as her employers and her lawyer.

The ways in which the women in the group engaged with forms of literacy associated with immigration were not confined to obtaining visas. Most of the women travelled back to Nepal before returning to the UK during the period over which this research was conducted. In a number of sessions the women explained how stressful travelling alone could be and described the feeling of getting nervous, knowing that they would be asked to fill in a form on landing or worrying that they might not be able to read signs or departure boards. In dealing with such literacy demands they said they often had to rely on strangers as literacy intermediaries, something that they clearly found problematic:

Sudha, Jyothi and Sunita again talked about how difficult travel is when you can't read and write - not just filling in the forms, though that is a big thing but also reading signs, boarding cards etc and always having to ask people the way. Sudha said that here people are always really helpful but that isn't true in India where sometimes people don't want to help or send you the wrong way. She also described the trip she made to Spain when she had to change 3 or 4 times, and how in Spain it was so difficult because people didn't even speak English (observation notes 25/08/09) 
As they improved their literacy in English, managing the literacy demands related to travel and associated official immigration processes, without having to reach out to strangers in this way, became easier. As a result, they described feeling more comfortable and confident about the journeys themselves. When, after a couple of years of attending sessions, Sudha, for example, returned from a trip visiting family in Nepal and India, she was proud to tell me how she had managed to fill in immigration forms herself for the first time. Her experiences of this however had not been straightforward. She explained that, on leaving Nepal, when she had presented her form, the immigration official had asked her why she had filled in the form in English. She said that he then queried her UK visa status and asked her what she was doing leaving Nepal and going to the UK. She said that she told him she had to go to the UK as there were no jobs for her in Nepal, but that if he wanted to get down from his chair and give her his job stamping passports then she would be very happy to take it and stay in her own country. She said that after some discussion he then let her through (observation notes 19/01/11).

Sudha's retelling of this experience provides a powerful illustration of the complex and sometimes contradictory nature of the relationship between literacy, language, power and status that the women experience as they move between countries and negotiate official spaces, and shifts in positioning that these entail. In relating the story to me and the others present at the session she was proud to explain how she had both completed the form in English and had also stood up to the official when questioned. Here, her developing literacy skills in English as well as, importantly, the knowledge that she possessed a valid visa for the UK appeared to have helped to give her the confidence to assert herself in her dealings with the male official. However in her telling of the story she also reflected on her own ambivalence about her position as a migrant domestic worker, as she drew on it to remind us of her view that it was her lack of educational and economic opportunities in Nepal that 
meant that she had to migrate in the first place, something that she wished she hadn't had to do. Moreover, while, her emerging literacy skills in English were sufficient to enable her to negotiate the official literacies associated with the international space of the airport, and she was aware of the status they carried, she was also frustrated by her lack of literacy skills in Nepalese.

Although, as seen in the examples above, much of the women's engagement with official or elite forms of literacy was related to processes of immigration, there were a range of other ways in which they needed to be able to use official forms of literacy. In particular, the transnational nature of their lives, working for international employers, and their role in sending back remittances to Nepal and India were reflected in their dealings with transnational financial institutions, and the literacy practices that this entailed. On occasions, for example, they discussed and exchanged information about exchange rates during group sessions, and some group members referred to having bank accounts in more than one country. Sudha meanwhile explained the difficulties she experienced accessing her money in a bank account in India:

[Sudha] explained that she has a bank account in India which her employers had opened for her to pay her earnings into. However as she uses two names, one that is on her passport, and one that other people call her, her employers had opened it in the wrong name and so she couldn't get any money out of it.... So when she was in India, as well as visiting her son's school and meeting the teachers, she had to sort this out. She said she went to the bank and tried to explain the problem to them, and explained that her employers had just used her wrong name, and they said they needed to see something official confirming her identity otherwise she couldn't access the account. So... when she was back in her village in Nepal she had to go to the community leader and get them to write a letter or a document saying who she was 
and she said that they stamped this with some kind of stamp. Then she went back to India and took this document from her village in Nepal back to the bank. She said that they weren't very convinced by this document, and that it was very difficult [to convince them], but... eventually she managed to sort it out (observation notes 29/01/11).

Although Sudha's account is a little difficult to follow, her experience provides a fascinating example both of the challenges of negotiating finances - and the literacy practices associated with them - across geographical and cultural contexts and of the way in which texts themselves may take on different meanings as they move between these contexts. What was seen by Sudha as a very official document stamped by officials in her rural community in Nepal, was clearly much less convincing to the bank officials in urban India. However, despite this, Sudha appears to have eventually been successful in convincing them to accept it, thus enabling her to access her bank account.

Central to the negotiations between Sudha and the bank officials was the invocation of the concept of the official document, and a shared view of the importance of writing in asserting the facts in the face of the law, despite different perceptions regarding how such an official document should look. Thus, this account in common with other studies which examine migrant encounters with the literacies associated with immigration bureaucracies (for example, Bartlett et al., 2011; Vieira, 2013) highlights the way in which, for migrants such as Sudha, the authority of official texts creates a special status that may regulate and constrain, or unlock and make possible certain kinds of actions and movements. It also provides a powerful illustration of the way in which, the women in the group, were able to draw on their knowledge, initiative and social networks, as well as their emerging literacy skills in English, and find ways to successfully negotiate complex literacy demanding situations, in which they 
found themselves facing high status and well educated officials operating across global contexts.

\section{Discussion}

The ways in which the women in the group engaged with literacy, and how this interacted with the social relations they encountered in their everyday lives is complex and is intrinsically bound up their experiences as migrant workers. In contrast to women whose experiences of literacy are explored in ethnographic studies focusing on literacy in particular local contexts, where the social contexts which affect and are affected by literacy are often framed in terms of the immediate household or community, the women's experiences highlight the way in which, for them, literacy affects and is affected by social relations in multiple, and shifting spaces. How they are able to draw on their new literacy skills in English as cultural capital, and the way in which this is valued, affect and are affected by not only by their relationships with families but also by their movements as migrants, their position within their international employers' households and their transnational social networks. Their literacy practices, thus took on different meanings as they moved from one space to another. Obtaining basic literacy skills in English did not have a obvious significant effect on their low, and gendered, status within the households within which they worked. Similarly, although their emerging literacy skills were helpful as they negotiated visa applications, literacy was not the deciding factor in enabling them to obtain indefinite leave to remain, and, in negotiating this, they remained dependent on the support of lawyers and employers, and vulnerable to changes in government policy. However, when they moved outside of this space as they interacted their transnational networks of family and friends, and travelled back to their home communities, assuming a literate identity was clearly important to them. 
Paying attention to transnational nature of the women's lives is thus clearly important for understanding their engagement with literacy. As I discuss in more detail in an earlier paper (see North 2017), this had implications for the type of literacy and English language learning support they needed and wanted: while the women in the group valued the more formal English language learning that they received through attending ESOL classes on Sundays, as noted above, they often found the literacy demands of these classes very difficult, and struggled to engage with much of the content. Meanwhile, in the literacy support sessions that they attended with me, developing literacy skills that linked very directly to their transnational practices - sending SMS messages, or being able to complete travel documentation for example - was clearly a priority for them. This suggests a value in recognising, and engaging more closely with learners' own experiences of migration and mobility when developing literacy and English language programmes for migrant groups.

More widely, it also highlights the significance of paying attention to the complex nature of the relationship between the local and the global/trans-local/transnational when conceptualising literacy as a social practice in the context of migration. Like research undertaken by Kell (2006) in South Africa, my analysis suggests a need to problematicise "the binary concept of the local and the global" (p. 166), in relation to understanding literacy practices. However, while Kell argued that in her research it was not possible to define the 'global', only the 'non-local', my research suggests that defining 'the local' may be similarly problematic. Certainly the notion of 'the local' as a geographically, socially and culturally defined space cannot be easily applied to the transnational spaces that the women in my study inhabited, and which shaped their engagement with particular forms of literacy practice. Indeed the way in which the women encountered literacy, and drew upon their literacy practices, were closely tied up with the way in which they navigated across geographical and cultural boundaries, as they positioned themselves within international households and 
transnational communities. These communities of transnational migrants, were to some extent anchored in a symbolic notion of 'home' associated with the (distant) 'local' villages and countries which they left behind, and the connections to these that they shared, and in this way, to some extent a sense of the 'local' can also be found in those literacy practices that keep them connected to 'home' - Sudha's dashera message or the other SMS Facebook messages exchanged with friends, family and partners at home; or which are central to their experiences of reconnecting to their communities and families when they are able to travel back to Nepal - Sudha's 'grassroots' certificate confirming her identity, for example.

However, these literacy practices also had very global or transnational dynamics: the Dashera message connected women working across two different continents; Sudha's certificate confirming her identity was used in negotiations with an international bank in Delhi. Moreover, just as some of their literacy practices appeared to connect them back to the 'local' space of their 'home' communities, so others appeared to amplify their distance from this space, as they aspired to read 'western' novels like those they found in the international households in which they worked; or used their literacy in English to obtain leave to remain in the UK. The women's literacy practices thus played a role both in connecting back to the 'local' and moving away from it, in ways that involve processes of positioning, negotiation of status, identity and sense of self.

Literacy for the women in the case study group is clearly situated within the context of their lives as Nepali women and as migrant domestic workers in London. However this context, rather than being one that can be locally defined, could, drawing on Anthia's term be understood as "translocational", associated with multiple, complex and shifting spaces or locales, in which literacy - and the women's engagement with literacy in English - took on particular meanings. The women's literacy practices were situated within this translocational context, and their engagement with literacy was shaped by the social position, mediated by 
gender, class, ethnicity and immigration status, that they occupied as they moved between distinct spaces within it. However, as the analysis in this paper shows, these literacy practices were themselves involved in processes of positioning, as the women actively drew on their emerging literacy skills in English as they moved between spaces, and, in doing so, attempted to navigate the tensions and contradictions that their lives as migrant domestic workers entailed.

\section{References}

Anderson, B. (2000). Doing the Dirty Work? The Global Politics of Domestic Labour. London and New York: Zed Books.

Anderson, B. (2001). Different roots in common ground: Transnationalism and migrant domestic workers in London. Journal of Ethnic and Migration Studies, 27(4), 673683. doi: 10.1080/13691830120090449

Anthias, F. (2002). Where do I belong? Narrating collective identity and translocational positionality. Ethnicities, 2(4), 491-514.

Anthias, F. (2006). Belongings in a globalising and unequal world: Rethinking translocations. The situated politics of belonging, 17-31.

Anthias, F. (2008). Thinking through the lens of translocational positionality: an intersectionality frame for understanding identity and belonging.Translocations: Migration and social change, 4(1), 5-20.

Bartlett, L., Jayaram, K., \& Bonhomme, G. (2011). State literacies and inequality: Managing Haitian immigrants in the Dominican Republic. International Journal of Educational Development, 31(6), 587-595. doi: http://dx.doi.org/10.1016/j.ijedudev.2011.02.005 
Barton, D., \& Hamilton, M. (1998). Local Literacies: Reading and Writing in One Community. London: Routledge.

Barton, D., Hamilton, M., \& Ivanic, R. (Eds.). (2000). Situated literacies: reading and writing in context. Abingdon and New York: Routledge.

Baynham, M. (2007). Transnational literacies: Immigration, language learning and identity. Linguistics and Education, 18(3-4), 335-338. doi: 10.1016/j.linged.2007.10.002

Baynham, M., \& Prinsloo, M. (Eds.). (2009). The future of literacy studies. Basingstoke: Palgrave Macmillan.

Blommaert, J. (2001). Investigating Narrative Inequality: African Asylum Seekers' Stories in Belgium. Discourse \& Society, 12(4), 413-449. doi: 10.1177/0957926501012004002

Blommaert, J. (2008). Grassroots literacy: writing, identity and voice in central Africa. London: Routledge.

Brandt, D., \& Clinton, K. (2002). Limits of the Local: Expanding Perspectives on Literacy as a Social Practice. Journal of Literacy Research, 34(3), 337 - 356.

Briones, L. (2009). Empowering migrant women: Why agency and rights are not enough. Farnham: Ashgate.

Cheffy, I. (2011). Implications of local literacy practices for literacy programmes in a multilingual community in northern Cameroon. Compare: A Journal of Comparative and International Education, 41(2), 247-260. doi: 10.1080/03057925.2011.547284

Chopra, P. (2001). Betrayal and solidarity in ethnography on literacy. In B. V. Street (Ed.), Literacy and development: Ethnographic perspectives (pp. 78-91). London and New York: Routledge. 
Chopra, P. (2004). Distorted Mirrors: (De)centring images of the 'illiterate Indian village woman' through ethnographic research narratives. In A. Robinson-Pant (Ed.), Women, Literacy and Development: Alternative perspectives (pp.35-56). London: Routledge.

Cox, R. (2006). The Servant Problem: Domestic Employment in a Global Economy. London and New York: I.B. Tauris.

Glick Schiller, N.., Basch, L., \& Blanc, C. S. (1995). From immigrant to transmigrant: Theorizing transnational migration. Anthropological quarterly 68(1), 48-63.

Goody, J. (1986). The logic of writing and the organisation of society. New York: Cambridge University Press.

Goody, J., \& Watt, I. (1968). The consequences of literacy. In J. Goody (Ed.), Literacy in traditional societies. New York: Cambridge University Press.

Hamilton, M., \& Pitt, K. (2011). Challenging representations: Constructing the adult literacy learner over 30 years of policy and practice in the United Kingdom. Reading Research Quarterly, 46(4), 350-373.

Han, C., Starkey, H., \& Green, A. (2010). The politics of ESOL (English for speakers of other languages): implications for citizenship and social justice. International Journal of Lifelong Education, 29(1), 63-76.

Heath, S. B. (1983). Ways with Words: Language, Life and Work in Communities and Classrooms. Cambridge and New York: Cambridge University Press.

Heath, S. B. (1996). Ruling places: Adaptation in development by inner-city youth. In R. Jessor, A. Colby \& R. A. Shweder (Eds.), Ethnography and human development: 
Context and meaning in social inquiry (pp. 225-252). Chicago: University of Chicago Press.

Home Office. (2013). Knowledge of language and life in the UK for settlement and naturalisation: Statement of Intent, changes to the requirement from October 2013. Retrieved 11/10/17 from https://www.gov.uk/government/uploads/system/uploads/attachment_data/file/182545 Istatement-of-intent-koll.pdf.

Hondagneu-Sotelo, P. (2007). Domestica: Immigrant workers cleaning and caring in the shadows of affluence. Berkeley, LA: University of California Press.

Hondagneu-Sotelo, P., \& Avila, E. (1997). “I'm here, but I'm there”: The Meanings of Latina Transnational Motherhood. Gender \& Society, 11(5), 548-571. doi: $10.1177 / 089124397011005003$

ILO. (2015). Labour Migration Highlights No. 3: Migrant Domestic Workers. Geneva: ILO. Kalman, J. (2005). Discovering literacy: access routes to written culture for a group of women in Mexico. Hamburg: UNESCO Institute for Education.

Kell, C. (2006). Crossing the margins: Literacy, semiotics and the recontextualisation of meaning. In K. Pahl \& J. Rowsell (Eds.), Travel notes from the new literacy studies: instances of practice (pp. 147-172). Clevedon: Multilingual Matters.

Kell, C. (2009). Literacy practices, text/s and meaning making across space and time. In M. Baynham \& M. Prinsloo (Eds.), The future of literacy studies (pp.75-99). Basingstoke: Palgrave Macmillan.

Kell, C. (2011). Inequalities and crossings: Literacy and the spaces-in-between. International Journal of Educational Development, 31(6), 606-613. doi: http://dx.doi.org/10.1016/j.ijedudev.2011.02.006 
Lam, W. S. E., \& Warriner, D. S. (2012). Transnationalism and Literacy: Investigating the Mobility of People, Languages, Texts, and Practices in Contexts of Migration. Reading Research Quarterly, 47(2), 191-215. doi: 10.1002/rrq.016

Lutz, H. (2011). The New Maids: Transnational Women and the Care Economy. London and New York: Zed Books.

Lutz, H. (Ed.). (2008). Migration and Domestic Work: A European Perspective on a Global Theme. Farnham, UK and Burlington, USA: Ashgate.

Lutz, H., \& Palenga-Möllenbeck, E. (2011). Care, Gender and Migration: Towards a Theory of Transnational Domestic Work Migration in Europe. Journal of Contemporary European Studies, 19(3), 349-364. doi: 10.1080/14782804.2011.610605

Maddox, B. (2005). Assessing the impact of women's literacies in Bangladesh: An ethnographic inquiry. International Journal of Educational Development, 25(2), 123132. doi: 10.1016/j.ijedudev.2004.11.017

Maddox, B. (2007). What can ethnographic studies tell us about the consequences of literacy? Comparative Education, 43(2), 253 - 271.

Madianou, M., \& Miller, D. (2011). Mobile phone parenting: Reconfiguring relationships between Filipina migrant mothers and their left-behind children. New Media \& Society, 13(3), 457-470. doi: 10.1177/1461444810393903

McNay, L. (2000). Gender and Agency: Reconfiguring the Subject in Feminist and Social Theory. Cambridge: Polity Press.

McNay, L. (2008). Against Recognition. Cambridge: Polity Press. 
Meyers, S. V. (2014). Del otro lado: Literacy and migration across the U.S.-Mexico border. Carbondale: Southern Illinois University Press.

Moss, G. (2001). Bernstein's languages of description: some generative principles. International Journal of Social Research Methodology, 4(1), 17-19.

Moss, G. (2007). Literacy and Gender: Researching texts, contexts and readers. Abingdon: Routledge.

North, A. (2013). Reading and writing between different worlds: Learning, literacy and power in the lives of two migrant domestic workers. International Journal of Educational Development, 33(6), 595-603.

North, A. (2017). What kind of literacy? Reflections on the experiences of migrant domestic workers negotiating learning in London. European Education, 49(2-3), 184-200.

Nabi, R. (2009). Hidden literacies: Ethnographic studies of literacy and numeracy practices in Pakistan Bury St Edmonds: Uppingham Press.

Pahl, K., \& Rowswell, J. (Eds.). (2006). Travel Notes from the New Literacy Studies: Instances of Practice. Clevedon: Multiligual Matters.

Papen, U. (2007). Literacy and globalization: reading and writing in times of social and cultural change. Abingdon and New York: Routledge.

Parreñas, R. S. (2001). Servants of Globalization: Women, Migration and Domestic Work. Stanford, California: Stanford University Press.

Parreñas, R. S. (2005). Long distance intimacy: class, gender and intergenerational relations between mothers and children in Filipino transnational families. Global Networks, 5(4), 317-336. doi: 10.1111/j.1471-0374.2005.00122.x 
Pries, L. (2008). Rethinking transnationalism: the meso-link of organisations Abingdon and New York: Routledge.

Reder, S., \& Davila, E. (2005). Context and literacy practices. Annual Review of Applied Linguistics, 25, 170-187. doi: doi:10.1017/S0267190505000097

Robinson-Pant, A. (2001). Why eat green cucumber at the time of dying?: exploring the link between women's literacy and development : a Nepal perspective. Hamburg: UNESCO Institute for Education.

Robinson-Pant, A. (2004). Introduction. In A. Robinson-Pant (Ed.), Women, Literacy and Development: Alternative perspectives (pp. 1-10). London: Routledge.

Rockhill, K. (1993). Gender, Language and the Politics of Literacy. In B. Street (Ed.). Cross Cultural Approaches to Literacy (pp. 156-175). Cambridge: Cambridge University Press.

Sarroub, L. K. (2009). Glocalism in Literacy and Marriage in Transnational Lives. Critical Inquiry in Language Studies, 6(1-2), 63-80. doi: 10.1080/15427580802679419

Scribner, M., \& Cole, S. (1981a). The Psychology of Literacy. Cambridge, HA: Harvard University Press.

Scribner, M., \& Cole, S. (1981b). Unpackaging Literacy. In M. F. Whiteman (Ed.), Variations in Writing: Functional and Linguistic-Cultural Differences (pp. 71-87). Hillsdale, NJ: Lawrence Erlbaum Assocs.

Simpson, J. (2015). English language learning for adults in superdiverse Britain. In J. Simpson \& A. Whiteside (Eds.), Adult language education and migration: challenging agendas in policy and practice. London and New York: Routledge. 
Street, B. V. (1984). Literacy in Theory and Practice. Cambridge: CUP.

Street, B. V. (1994). Struggles Over the Meaning(s) of Literacy. In M. Hamilton, D. Barton \& R. Ivanic (Eds.), Worlds of Literacy (pp. 15-20). Clevedon: Multiligual Matters Ltd.

Street, B. V. (2003) What's "new" in New Literacy Studies? Critical approaches to literacy in theory and practice. Current issues in comparative education, 5(2), 77-91.

Tamtomo, K. (2012). Multilingual youth, literacy practices, and globalization in an Indonesian city: A preliminary exploration Paper presented at the 8th Northeast Conference for Indonesian Studies, Yale University, New Haven.

Vieira, K. (2013). On the Social Consequences of Literacy. Literacy In Composition Studies, $1(1), 26-32$.

Warriner, D. (2007). Transnational literacies: Immigration, language learning, and identity. Linguistics and Education, 18(3-4), 201-214. doi: 10.1016/j.linged.2007.10.003

Warriner, D. (2009). Transnational literacies: examining global flows through the lens of social practice. In M. Baynham \& M. Prinsloo (Eds.), The future of literacy studies (pp. 160-180). Basingstoke: Palgrave Macmillan. 